\title{
The Expansion of the Special Customs Regimes for the Improvement of Logistics
}

\author{
Dimitra Stefani, Michail Papoutsidakis, Aikaterini Sfyroera, George Priniotakis \\ Department of Industrial Design and Production Engineering, University of West Attica, Athens, Greece \\ Email: mipapou@uniwa.gr
}

How to cite this paper: Stefani, D., Papoutsidakis, M., Sfyroera, A. and Priniotakis, G. (2021) The Expansion of the Special Customs Regimes for the Improvement of Logistics. Open Journal of Applied Sciences, $11,1-8$.

https://doi.org/10.4236/ojapps.2021.111A0 $\underline{01}$

Received: September 20, 2020

Accepted: December 15, 2020

Published: December 18, 2020

Copyright $\odot 2021$ by author(s) and Scientific Research Publishing Inc. This work is licensed under the Creative Commons Attribution International License (CC BY 4.0).

http://creativecommons.org/licenses/by/4.0/

\begin{abstract}
Logistics is one of the main sectors in Greece and constitutes an important source of income, representing $10.85 \%$ of GDP, and amounts to 19.8 billion euro (according to a study EEL in 2014). The developments that have been observed in the logistics sector in relation to the ports over the last years have created the need to make ports part of the supply chain in order to provide value added services to customers. Ports and especially those for container ships are evolving rapidly, providing integrated solutions for the improvement of logistics. The free trade zones, the freight transport centers and container transport hubs are part of the ports with an ever-increasing role in the management of supply chain and logistics. During last years, the port of Piraeus has become a central gateway to the European market from third countries. In addition to the port's location, the warehouse center within the Piraeus Free Zone is also an important asset. The Free Zones are part of the customs territory of the European Community where non-Community goods which are under suspension of payment of import duties, taxes and commercial policy measures may enter and be stored until they are assigned a new customs regime [1]. Moreover, an important percentage of 3PL companies in Greece have been assigned as Authorized Economic Operators. This characteristic provides them the jurisdiction to use simplified customs procedures during import and export procedures. More and more companies are keen on using special customs regimes in Piraeus Port, as they intend to use Greece as their strategic hub in logistics in Europe or start trading within the country. Efficient procedures prior and during customs clearance can have a significant impact on eliminating delays, reducing administrative costs and improving the overall management of the supply chain. The benefits that will arise in favor of logistics by the use of special customs regimes are following: 1) Facilitating foreign trade by providing incentives for the collection and distribution of goods, thus contributing to the development of transit trade. 2) Support for business in logistics. 3) Possibility to provide VAT-exempt
\end{abstract}


services in storage areas. 4) Possibility of transferring the ownership of goods, with VAT exemption, into storage areas. 5) Liquidity savings for firms. 6) Storage capacity of large quantities of goods. 7) Possibility of combining VAT facilities and simplified customs procedures. 8) Facilitating the channeling of domestic goods into international markets. 9) Investment and growth in work positions.

\section{Keywords}

Logistics, Customs, Regulations, Port Regulations, Transit Trade, Supply Chain

\section{Introduction}

Ports are currently characterized by many changes in their role. Shipping is currently more interested in providing door-to-door transport services and value-added services, a development that has been largely made by the integration of traditional liner shipping companies, ports and logistics companies. Changes in shipping companies, which are the main customer of the ports, have prompted ports to adapt to their needs and expectations. In addition, developments and changes in supply chain and logistics such as:

- Globalization of production,

- The use of outsourcing services,

- Trends in the restructuring of the network of regional and local distribution centers,

- The development of combined transport linking strategic maritime, rail, road and inland waterway transport,

- Advances in technology,

- The power of information technology,

- Reducing the life of products,

- Changes in demand for various goods,

- Implementation of Total Quality and JIT (Just-In-Time) practices,

- Responding to customers' demands at shorter times, and

- Better transmission of information and knowledge between those involved in the supply chain

have created exceptional pressure on ports to reorganize logistics and redefine their strategies and objectives to maintain their competitive position in the market. Moreover, bearing in mind that ports are the most vulnerable area in the supply chain and are constantly exposed to the demands of the parties concerned, in an extremely mobile, all these developments are having more serious consequences for them than for other operators in the supply chain. Developments in logistics and the port environment have created the need to make ports part of the supply chain network in order to provide value added services to customers. Ports have been evolved from a simple point of import/export of 
products to a transit and industrial operations center within a logistics system. They have evolved into product-valuing points and are the central connectors of the supply chain and the transport chain, providing single transport facilities with a strong interconnection with other modes of transport. They operate by providing systemic logistics, which require a high level of coordination and connectivity. One of the definitions attributed to ports and emphasizing their role in the supply chain defines the port as an industrial hub and logistics center within the global transport system, with a strong maritime character, with grouped activities carried out and directly or indirectly linked to the uninterrupted transport within the supply chain. In addition to their traditional roles, seaports should be regarded as logistics centers, industrial zones and centers of commerce. The free trade zone, freight transport centers and container transport stations are part of the ports as commercial and industrial centers, with an ever-increasing role in the management of supply chain networks and logistics [2].

\section{Logistics}

According to the Supply Chain Management Professional Council (CSCMP), logistics are the part of the supply chain that plans, implements and controls efficient and effective forward and backward flow and the storage of goods, services and related information between the point of origin and the point of consumption to meet customer requirements.

Companies rely on logistics systems to transport goods and goods and to manage the flows of information required to perform them. Logistics integrates a wide range of business activities, such as:

- Transport

- Storage

- Commodity Management

- Packaging

- Stock Management

- Logistics

Logistics in supply chain management are perhaps the only way to deal with international competition not only in Greece but worldwide as well.

The development of containers was the basis for the development of combined transport.

This shows that ports have evolved from a simple point of import/export of products to a transit and industrial operations center within a logistics system.

Designates the port as an industrial hub and logistics center within the global transport system, with a strong maritime character, with grouped activities carried out, directly or indirectly linked to seamless transport within the logistics chain.

Facilitating trade and the need to simplify and accelerate export and import procedures is an important element of the supply chain agenda. Facilitation also includes activities under the control of the customs administration within the country (special procedures), as well as arrangements concerning ancillary pro- 
fessions such as customs agents. According to the Logistics Index (LPI), Greece ranks 44 in the global ranking taking into account the data from 2012-2014-2016-2018.

\section{Customs Regimes}

The free trade zones, freight transport centers and container transport stations are part of the ports as commercial and industrial centers, with an ever-increasing role in the management of supply chain networks and logistics

Piraeus is the first port to be approached by container ships from Asia to Europe following their passage through the Suez Canal in Egypt. In recent years, the port of Piraeus has become a central gateway to the European market from third countries. In addition to the port's location, the management and storage center within the Free Zone of the port of Piraeus is also an important asset.

The Free Zones are part of the customs territory of the European Community where non-Community goods which are under suspension of payment of import duties, taxes and commercial policy measures may enter until they have been assigned a new customs regime and domestic goods which are scheduled to be exported.

Free Zones form a special customs regime allowing the storage of non-European goods in the customs territory of the European Union. These goods, during their stay in the free zones, are not subject to customs duties and other charges, as well as commercial policy measures, provided that these measures do not involve a prohibition on entry or exit from that customs territory [3].

Union goods may be imported, stored, moved, used, processed or consumed while in a Free Zone. In such cases, goods are considered not to be under the Free Zone regime. Non-Union goods may, while remaining in a free zone is released for free circulation in local market or placed under different customs regime. In such cases, the goods shall not be considered to be under the free zone regime. Free Zones are enclosed parts of the customs territory of the Union whose perimeter and entry-exit points are subject to customs supervision. Facilitating trade across the Greek border, through simplified, effective and digital procedures, is a very important factor for companies that intend to use Greece as a strategic hub of their logistics in Europe, or to begin trading with Greek organizations. Thus, the facilitation of commercial and customs operations, particularly in Greek ports, can significantly improve both imports and exports. Efficient procedures before and during customs clearance can have a significant impact on eliminating delays, reducing administrative costs and improving the overall management of the supply chain [4].

One significant progress was the implementation of the new integrated customs information system (ICISnet) in 2013, which greatly facilitated the electronic submission of customs declarations. Incentives for setting up an AEO (Authorized Economic Operator) were also adopted. The great advantage of an AEO $s$ is that they enjoy customs simplifications and facilitation in terms of security and safety-related customs controls. 
An economic operator shall be the natural or legal entity who participates in activities covered by customs legislation.

Every economic operator, established within the customs territory of the Union and fulfilling the following criteria may apply for the certification of authorized economic operator.

The advantages of an AEO are following:

- It is subject to fewer physical inspections based on documents than other economic operators

- When an AEO is subject to any physical or documentation, those checks shall be carried out as a priority

- When an AEO's cargo is subject to customs inspection, the AEO will be notified in advance

- At the request of an AEO, customs inspections may be carried out at a different location of the one initially defined from customs

In the last few years, and especially since the 2016's adoption of the new Customs Code, it has become vital for companies in international trade to obtain the certification of the authorized economic operator. All these simplifications of the procedures being offered constitute a competitive advantage for the majority of economic operators such as importers/exporters, carriers and other operators in the supply chain. During an export procedure, the consignee of the goods was obliged to issue an invoice including VAT. The same invoice was issued after a credit by the customs authorities, upon receipt of the application for tax exemption within 40 days from the issuance date of the invoice. In this case, the company was responsible for the export of the consignment, the processing of the export declaration and the application for VAT exemption. If for any reason, for instance delayed arrival of the goods at the destination, the customer was obliged to pay the VAT.

Under the new legislation (POL. 1026/16.02.2016) for the exemption of VAT in the Free Zones, the customer shall issue an invoice free of VAT [5].

The favorable VAT exemption regulation in force in the Free Zone has now been applied to warehouses located in the wider Piraeus region and to logistics undertakings. It is also worth mentioning that it is now usual for a 3PL provider to undertake the whole process. In recent years, a significant proportion of the 3PLs, airlines and shipping companies, have been certified as Authorized Economic Operators (AEOs) in Greece [6].

\section{Conclusions}

The efforts to expand the internal market reduce barriers to international trade and investments and the need to keep safe and secure borders of the European Union have altered the role of customs authorities, which are now playing a decisive role in the supply chain and in the supervision and management of international trade. They are a key factor in the competitiveness of countries and businesses. Customs legislation should therefore reflect economic reality, as well as the new role and mission of the customs authorities. 
The port of Piraeus as a free zone port is part of the customs territory of Greece and thus of the European Union.

Goods imported from third countries for as long as they remain in the free zone shall be considered as not have entered European territory and temporarily exempted from the imposition of import duties, taxes and trade policy measures. Those goods may be processed and repackaged or even covered by specific European processing arrangements, with an exemption from the customs authority's obligation to issue an authorization for re-exportation. Third, country goods which are to be promoted in other EU countries may make use of European provisions to defer VAT applied by Greece, which, in conjunction with the free zone, is a unique tool for minimizing costs and improving company cash flow.

Many companies are already using not only the free zone in the port of Piraeus for the system of exemption and reversal of value added tax in Greece (i.e. payment of import duties only and not VAT) but also the customs regime 42, which suspends the payment of VAT on the import of goods which will be directly delivered to other EU countries.

For example, ship building companies and ship repair companies, who will soon need tax exemption in Greece, will gain benefit from the fact that they will operate within the free zone.

The status of authorized economic operators will become a standard for all companies with international commercial activities in the following years. The partnerships developed between EU countries and countries such as the USA, Japan and Norway were based on the mutual recognition of programs aimed at the status of approved economic operators. These partnerships improve security and enhance the value of the global supply chain, while the companies involved in this process have a low risk profile [7].

In countries with a low logistics performance index, external trade operations require more time and entail higher costs for exporters/importers due to the unforeseen and uncertain supply chain system. The causes of such a supply chain system may include increased controls, lack of confidence in the activities of inspectors, lack of quality of logistics infrastructure.

The implementation of the concept of e-customs, which is scheduled to come into operation by the end of 2020, will bring about some positive changes with a direct impact on business. However, the implementation of software programs and the acquisition of hardware support will require significant investments and planning on their part, as well as the planning of extensive financial and operational plans [8].

The current process of modernizing customs procedures in the European Union is in the process of legislative implementation, and a number of annexes necessary for the implementation phase are in preparation. Given the strict time frames and the substantial changes mentioned above, it is likely that the adjustment process for both companies and national bodies will be difficult and will lead to the original set deadlines being exceeded [9]. 


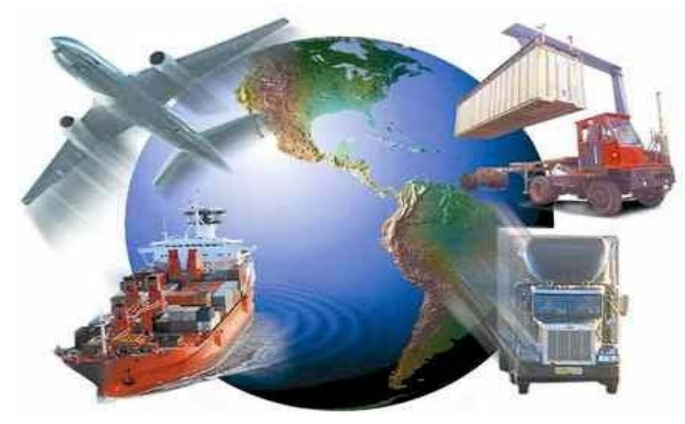

Figure 1. Representation of global transportations.

Another variable to be considered concerns the maintenance of software systems and management and communication platforms. Information systems should be flexible and adaptable to include more than customs authorities. Nowadays, there are a lot of modern ways of transportation of materials and goods (Figure 1) that every logistics company should take under serious consideration in order to proceed in a safe and furthermore on time delivery of ordered parts, kits etc.

In conclusion, best practices in customs procedures, i.e. the status of authorized economic operators, simplified customs procedures, postponement of payment of customs duties, risk management based on a new philosophy, are prerequisites for the development of logistics worldwide.

\section{Acknowledgements}

All authors would like to thank the University of West Attica and specifically the Post Graduate Program of Studies (MSc) "New Technologies in Shipping and Transport", for the financial support provided to them to undertake this research project.

\section{Conflicts of Interest}

The authors declare no conflicts of interest regarding the publication of this paper.

\section{References}

[1] United Nations (2002) Commercial Development of Regional Ports as Logistic Centers, New York.

[2] Association of Customs Agents, Piraeus, Athens (2017) Customs Formalities - Procedures and Controls, Piraeus, SY.E.TA.PA.

[3] E.2176/2019 Directives on the Movement of Goods to/from the Free Zone-Application of the number. DDTHEKA D1144720 EX2018/27-9-18 Decision AADE Commander (FEK 4513/B/15-10-18) on "Establishment and Functioning of the Free Zones".

[4] Mavros, T. and Panagiotopoulos, G. (2019) Join the Greek Logistics Hub. Supply Chain \& Logistics, Special Edition, 16-63.

[5] EY (2016) Greece-International Commercial Center, Athens, Annual Creativity 
Report.

[6] Fourkas, S. (2018) Customs Legislation, Customs Legislation and VAT, Legislation on Customs Brokers, Piraeus, SY.E.TA.PA.

[7] EY (2017) Greece-International Commercial Center, Athens, Annual Creativity Report.

[8] Gani, A. (2017) The Logistics Performance Effect in International Trade. The Asian Journal of Shipping and Logistics, 33, 279-288. https://doi.org/10.1016/j.ajsl.2017.12.012

[9] IBHS (2019) Mapping Greek Logistics. Supply Chain \& Logistics, 102, 18-30. 